\title{
Film Studies Before Film Studies: Derek Jarman at the Slade
}

The growing scholarly interest in the history of film studies has arisen from and in response to the discourse on the subject's perceived disintegration. In their collection Inventing Film Studies, Lee Grieveson and Haidee Wasson write of the 'widespread sense of uncertainty and, in part, insecurity about the future of film study' which has accompanied the 'proliferation of moving image forms and cultures'; 1 but set out to demonstrate that 'the ideal of consolidation and clear identity often implied by conventional histories of film studies' is belied by 'the fragmented nature of the field' in the past. ${ }^{2}$ Meanwhile Duncan Petrie and Rod Stoneman, in their book Educating Film-Makers, lament the professionalization of the academy and the commercialization of the film schools, and reconstruct a past in which 'theory and practice were frequently interdependent and mutually reinforcing facets of the educational process' as a 'crucial reminder' for the impoverished present. ${ }^{3}$

Though the field has not been comprehensively mapped, it is nonetheless striking that in both books, and in the major monograph on the discipline's history in Britain, Terry Bolas's Screen Education, there is scarcely a mention of the country's first university film department; striking not simply because it was the first, but because its history is so germane to these concerns. Established in 1960, the Slade Film Department - housed in the Slade School of Fine Art, a department of University College London - does not warrant an index entry in Bolas's book, and is mentioned just once in Grieveson and Wasson's, only to be dismissed. The relevant chapter takes the form of a dialogue between Laura Mulvey and Peter Wollen intended to record the contribution of Paddy Whannel, head of the British Film Institute's education department in the 1960s, 'to the establishment of film studies as a recognized discipline'. ${ }^{4}$ When Mulvey brings up the Slade, Wollen replies that:

Paddy came from a very different intellectual background. His world was the world of people like Raymond Williams; it was not a nuts and bolts world, it was a structured intellectual world. Most important of all, he was interested in popular, commercial cinema. This was a complete break with tradition. ${ }^{5}$

The implied image of the Slade Film Department as tradition-bound, untheoretical, and hostile to commercial cinema is not altogether contradicted by more sympathetic observers. In his book on the department's chief lecturer Thorold Dickinson, Jeffrey Richards writes that the Slade course represented 'the intellectual and ideological legacy of the Film Society', disbanded in 1939; that the 'exciting, pioneering work' of Cahiers du cinéma and Movie 'made no impression on' Dickinson; and even that Citizen Kane (1941) was 'the only Hollywood film to be included' in his screening series. ${ }^{6}$

As Grieveson and Wasson rightly say, the general tendency has been to treat 'May 1968' as the founding moment of film studies, and as the 'complete break with tradition' which Wollen describes in their book. Their corrective view that it in fact 'marks a continuity with and not a break from earlier traditions of study' is one which the history of the Slade Film Department partly confirms, partly contradicts. ${ }^{7}$ What it confirms unequivocally, however, is their sense of the 'longstanding interdisciplinarity of film study', well before its supposed 
fragmentation, and of its 'imbrication with filmmakers, cinephiles, artists, collectors, galleries, museums, cooperatives, and marginalized political groups organizations beyond the university'. ${ }^{8}$ What follows is an attempt to trace the legacy of the Slade Film Department through the career of one of its beneficiaries, Derek Jarman, made for the light it sheds on the possibilities of 'imbrication'; on the discipline's constitutive interdisciplinarity; and on the relationship between film theory and film practice.

Jarman, who studied for a fine art diploma at the Slade between 1963 and 1967, encouraged the impression that he was only a filmmaker by accident, and both he and his critical champions have played down the extent of his film education. Michael O'Pray has written that 'Jarman is not a film-maker immersed in film history at all', ${ }^{9}$ and Jarman claimed that 'I've never read film theory and never bought a cinema book unless I was interested in a life. I've two bookshelf feet of Pasolini, Murnau, Cocteau, Eisenstein and Buñuel'.10 But it should be at least suggestive that in 1964-5, the year during which, according to his biographer Tony Peake, cinema 'was starting to figure with some prominence on Jarman's cultural agenda', films by all these directors except Pasolini, whose third feature Il vangelo secondo Matteo/The Gospel of St Matthew (1964) was shown at that year's London Film Festival, were screened by Dickinson at the Slade. ${ }^{11}$

In the department's early years, Dickinson supervised two postgraduates, ran a seminar for a small group of initiates, and arranged and introduced screenings which were formally open to all members of the University of London, and informally to others. He converted UCL's 160-seat Physics Theatre into a stateof-the-art auditorium, capable of handling widescreen formats, and 'fire-proofed and licensed for the showing of the early inflammable nitrate film'. ${ }^{12}$ Most of the first full year of screenings in 1961-2 was given over to a history of French cinema from the Lumières to Truffaut, including on successive days in March 1962 Clouzot's Les Diaboliques (1955) and one of its intertexts, Hitchcock's Psycho (1960), one of the many Hollywood films shown over the course of Dickinson's decade at the helm. According to Charles Barr, who joined as a postgraduate in 1961, Dickinson made the department's facilities available to Ian Cameron and other 'Movie people', so that 'the second issue of Movie, on Otto Preminger, was researched entirely in that place'.13

Like most of the 'Movie people', Jarman was not formally attached to the department, but unlike them he was fully entitled to attend screenings. Though he did not enrol at the Slade until 1963, his association with it began earlier. He had won a place in 1960, and while his father insisted that he take an academic degree at King's College London first, he attended life-drawing classes at the Slade throughout the duration of his King's course. For most of his time at King's, Jarman lived with his parents in the suburbs and by his own account did not see much of London; but he moved to a flat in Bloomsbury - closer to the Slade than to King's - in the autumn of 1962, as his final year began. By then Jarman was already a cinephile. He described seeing La Dolce Vita (1960), which opened in London during his first year at King's, as 'the moment when I realized that film could really interest me; that it could be more than just a way of filling in a rainy afternoon. At university everyone was interested in Italian films, especially those of Fellini or Antonioni.' ${ }^{14}$ The Slade may have fed this interest. 
During Jarman's last year at King's, Dickinson mounted a second year-long national survey, this time of Italian films. Numerous titles, including De Sica's Ladri di biciclette/Bicycle Thieves (1948) and Umberto D (1952), which were not otherwise available at the time, and others, such as Rossellini's La nave Bianca (1941), which had never been shown in Britain, were supplied by the Cineteca Nazionale. The programmes for May-June 1963 included three Fellini titles - I Vitelloni (1953), La Strada (1954), and La Dolce Vita - and three by Antonioni Le Amiche (1955), L'Avventura (1960), and La Notte (1961). It seems at least possible that Jarman, who was eligible to attend these screenings as a University of London student, who was certainly present at the Slade some of the time, who was interested in Italian films (some of the most famous of which were otherwise impossible to see), and who lived ten minutes' walk away from the venue, was exposed to this important influence through Dickinson's efforts.

One may be more confident about the years that followed. 'Like all of us he was addicted to film, attended as often as possible and absorbed the films,' recalls Lutz Becker, who joined the Slade in $1966 .{ }^{15}$ By the time Jarman enrolled in 1963, Dickinson was putting on at least three screenings each week. Though he rarely spoke - or was rarely asked - about these screenings, Jarman gave quite a full reply to his Slade contemporary Timothy Hyman:

I attended films, but I wasn't aware of film at that time as a potential area to work in. The theatre - or at least the design side - was more attractive. The films I admired (Cocteau's Beauty and the Beast, Ivan the Terrible, the Kenneth Anger and the Warhol films) were all part of the way one was growing up in the Art School; the sort of films you'd expect a painter in those years to be involved in. But I always loved Marienbad. And there was also, generally, German films - Pabst, Von Stroheim, Lang - so that even when I went on to work for Ken Russell, I built sets for The Devils that immediately echoed that Weimar period. ${ }^{16}$

Though his first year is the least well-documented so far as the film department is concerned, the existing evidence substantiates his reference to 'German films' of the Weimar period. Murnau's Der letzte Mann/The Last Laugh (1924), Pabst's Die freudlose Gasse/The Joyless Street (1925), Dupont's Varieté/Vaudeville (1925) - as well as Von Stroheim's Greed (1924), not of course, German - all seem to have been shown in 1963-4.17

The main screening series in 1964-5 - the decisive year according to Peake, as we have seen - was called 'The Subjective Cinema', beginning with the third part, 'The Modern Film', then in the winter term going back to the silent era. 'The Modern Film' term took in multiple Godard films, one apiece by Rivette and Malle, Marker's Le Joli Mai (1963) and Fellini's 81/2 (1963) - both released in Britain within the previous twelve months - and three films by Alain Resnais, including, on 8 December, L'Année dernière à Marienbad (1961). The second term concentrated on German and Soviet films of the 1920s; the third, which covered the sound film, included Cocteau's Orphée (1950), a key film for Jarman. (It had previously been shown in February 1962, as part of the long French season.) There was a similar spectrum of films in 1965-6, with three terms of film history and a secondary term-long series devoted to 'The Flexible Camera' - 
films made using the lightweight filmmaking technology that had come into use during the 1950s and which Jarman himself would use extensively.

Peake, whose biography was based on conversations with Jarman as well as his journals, names Humphrey Jennings as among the significant influences Jarman first encountered at the Slade. In January 1966, as part of the film history series, Dickinson organized a Jennings triple-bill consisting of Listen to Britain (1942), Fires Were Started (1943), and The Silent Village (1943), none of them widely screened at the time. The first of these in particular has been cited as an intertext of Jarman's state-of-the-nation film The Last of England (1987). Annette Kuhn, in the culminating chapter of Family Secrets, titled 'A Phantasmagoria of Memory', makes an extended comparison of the two films, both of them collages 'of memory-images and memory-sounds [...] as if drawn from a commonly held store of visual and auditory currency', both 'very much products of the cutting room, assemblages of disparate pieces of visual material, some of it originally shot for other purposes'.18

Dickinson, like Jennings, belonged to the generation of filmmakers and critics who had adopted Pudovkin's credo 'The foundation of film art is editing.'19 During an interview with Raymond Williams's collaborator Michael Orrom in 1961 he called editing the element which in my opinion takes the film as a recording instrument and makes it into a potential art'. ${ }^{20} \mathrm{He}$ did, however, modify his views quite rapidly. While Dickinson was not himself an original theorist, he was no mere nostalgist, and the Slade accommodated and generated new ideas as well as serving as a cinémathèque; its work was not made irrelevant by the events of 1968 . Indeed, the terms Wollen uses to praise Whannel - 'It wasn't simply a question of taking established ideas about film and putting them into some kind of curriculum' - are equally applicable to Dickinson. ${ }^{21}$

In 1964, when the Slade and the BFI were engaged in devising a diploma course, Dickinson complained that in the proposed curriculum which Whannel had helped write, 'the giant step forward in the last ten years is scarcely acknowledged at all'.22 In the same year, Dickinson declared that 'montage is no longer the kingpin of the unified film' and began to espouse a kind of Bazinianism, ${ }^{23}$ citing Budd Boetticher's CinemaScope western Ride Lonesome (1959), one of the Movie favourites in which, as Barr recalls, Dickinson was 'ready to be at least interested', as evidence of a new phase in cinema aesthetics. ${ }^{24}$ Widescreen, in Dickinson's account, had changed the terms of montage, but retained its essence. 'Selection, timing and emphasis,' he wrote, 'those three assets of montage, are injected on the floor with the help of the increasing fluidity of the camera.'25

Montage, then, remained central to Dickinson's pedagogy; Eisenstein's films were a staple of Slade screening series throughout the 1960s; and in turn Eisenstein and montage, as Kuhn suggests, became central to Jarman's practice, particularly after Imagining October (1984). An explicit act of homage which begins with Peter Wollen going through Eisenstein's library in Moscow, this short film was, as O'Pray puts it, 'for many a turning point in Jarman's career', convincing the doubters of his seriousness. ${ }^{26}$ 'Many of the books', Jarman recounted, 'were bought at Zwemmer's in the Charing Cross Road, they still had the receipts in them.' ${ }^{27}$ As Jarman may or may not have known, Eisenstein, 
during the same visit, made in late 1929, gave a series of lectures, probably in Foyle's bookshop, a stone's throw from Zwemmer's, to a group of Film Society members which included the young Dickinson. Jarman's visit to Moscow could be seen as a kind of symbolic return.

What Dickinson said when introducing screenings is in most instances a matter of conjecture, but he and Jarman certainly shared the belief that the lessons of the Soviet masters applied not only to the by then thoroughly respectable cinema, but also to lowlier forms. In a 1969 lecture which demonstrates Dickinson's embrace of the 'proliferation of moving image forms' television programmes had been screened almost since the beginning Dickinson deplored the 'people who call themselves educators who see no connection between Eisenstein's OCTOBER and the television commercial'.28 Jarman, similarly, believed that the music video, of which he was himself a practitioner, 'could be the most vital new language, re-introducing the silent image, with an emphasis on style.'29

The Jarman film most marked by his Slade education is probably War Requiem (1989), in which he was obliged, as in his music videos, not to tamper with the soundtrack, giving him an opportunity to 're-introduce the silent image' at feature length. Having decided to make extensive use of 'found' (or sought) footage, Jarman engaged a researcher, Lynn Hanke, to 'find four hours of warfare with no money', later assigning the footage to John Maybury for editing. ${ }^{30}$ In his published production diary, Jarman ponders: 'What documentary footage will we find with so little time? How do you make a silent film these days? I've been looking at Eisenstein's and Vidor's use of montage in the last two weeks' ${ }^{31}$

The decision to include such footage could have come to Jarman from any number of sources, but it is worth exploring some parallels between this project and what was arguably the most original line of research pursued by the Slade Film Department two decades before. In 1962 Dickinson put on a special series for UCL's history department, titled 'A Film Record of the 1930s', which included a mixture of newsreel, documentary, and feature material - a far from isolated example of the department's enthusiastic interdisciplinarity. This and subsequent series led to a collaboration with A. J. P. Taylor, whose UCL lectures in the late 1960s were accompanied by increasingly ambitious film programmes, largely the responsibility of Lisa Pontecorvo, a postgraduate student whose thesis was 'a study of the compilation of factual and actuality film in the recording of modern history'. ${ }^{2}$ In his War Requiem diary Jarman compares British, German, and Soviet propaganda techniques, echoing the theme of the two Pontecorvo series he is most likely to have seen, 'War and Revolution in Europe in the Twentieth Century' in 1965, and 'The Second World War from the Point of View of Six Nations' in 1966. Shortly afterwards, Pontecorvo's work helped bring into being the Slade Film History Register, a subject index of film material of all kinds, still in use in the 1980s, primarily for historians and researchers - very possibly including Hanke.

The Slade Film Department's unique situation as part of an art school based in a university, or as a university department based in an art school, partly accounts for Wollen's suggestion that it was concerned with 'nuts and bolts'. This was a widely held view at the time, and had to be refuted. Dickinson recalled in 1963 
that when the department opened, 'almost everyone assumed it was meant to be a school for training in the crafts of cinema'. ${ }^{33}$ Speaking in favour of the establishment of just such a school, he emphasized 'the difference between the university approach to cinema and the training school approach: they are vitally different'. ${ }^{34}$ Dickinson did however encourage his students to gain filmmaking experience, forging an alliance with the Nuffield Unit for the History of Ideas, a short-lived body which he had helped find accommodation near the Slade; in describing these manoeuvres he said that his course as a result 'will cease to be wholly theoretical'. ${ }^{35}$ In other words, he attempted to achieve the unity of theory and practice which Petrie and Stoneman hold up as an ideal in the present.

The fact remains that Jarman did not start making films until 1970, three years after he left the Slade. Becker says his career 'was expected but in no way predictable'. ${ }^{36} \mathrm{Had}$ Jarman begun at the Slade later or earlier, it might have been different. Before his time there had been more Slade-related filmmaking through the Nuffield unit, disbanded in 1964; after his time, there came into being the Slade Film Unit, and with it some provision for filmmaking, including Super-8 equipment. 'Use of the film by other artists - painters, sculptors, writers - is becoming more and more popular', wrote Mirek Dohnal, the unit's research assistant, in 1969, 'and a growing number of Slade students and staff want to make films.' ${ }^{37}$ However, the unit had been accommodated just as funding dried up as a result of the budgetary 'squeeze' of 1967-8.

In February 1969 the Slade's teaching staff met to discuss 'the demand for, and the provision of film and audio-visual facilities'. ${ }^{38}$ William Coldstream, the school's director, who had been instrumental in setting up the department, wondered whether the school could not buy 'one or two inexpensive cameras'. Dickinson, however, was pessimistic, and 'said he hoped to leave the film department as a going concern but the squeeze had frustrated this, particularly on the line of production'. He was not prepared simply to hand out uninsured cameras to untrained students. Later in the year Dickinson had to turn down the opportunity for the Slade Film Unit to make a film with the Ballet Rambert - with which Jarman had worked in 1968 as a set designer. 'If the Slade Film Department had developed on the lines laid down in the quinquennial plans, lines which were prohibited by the financial squeeze of January 1968,' he wrote to Coldstream, 'we should by now have been in a position to co-operate formally on a project of this kind.'39

Dickinson's tenure at the Slade, which ended in 1971, had its share of uncertainty and insecurity, and does not constitute a 'lost whole' to be contemplated from the fragmented present. Nor, however, is the Slade Film Department of the 1960s some institutional oxbow lake, terminally cut off from the course film studies took in later decades. In important respects, especially its openness to 'screen media' far beyond the fiction feature and documentary canons, it resembles the discipline's present more than its recent past. In others, as the record shows, potentially fruitful lines of continuity were broken; but this was less by design or supersession than as a consequence of pressures that are themselves quite familiar today. 
${ }^{1}$ Lee Grieveson and Haidee Wasson, 'The Academy and Motion Pictures', in Lee Grieveson and Haidee Wasson (eds), Inventing Film Studies (Durham, NC: Duke University Press, 2008), pp. xvi-xvii.

2 Ibid., p. xxix.

${ }^{3}$ Duncan Petrie and Rod Stoneman, Educating Film-Makers: Past, Present and Future (Bristol: Intellect, 2014), p. 4; p. 8.

${ }^{4}$ Laura Mulvey and Peter Wollen (with Lee Grieveson), 'From Cinephilia to Film Studies', in Inventing Film Studies, p. 217.

5 Ibid., p. 218.

6 Jeffrey Richards, Thorold Dickinson: The Man and His Films (London: Croom Helm, 1986), p. 180.

${ }^{7}$ Grieveson and Wasson, 'The Academy and Motion Pictures', p. xvi.

8 Ibid., p. xxix.

${ }^{9}$ Michael O'Pray, Derek Jarman: Dreams of England (London: British Film Institute, 1996), p. 9.

10 Derek Jarman, Smiling in Slow Motion (London: Century, 2000), p. 188.

11 Tony Peake, Derek Jarman: A Biography (London: Little, Brown, 1999), p. 112.

12 UCL Slade Film Department archive, Box 7b: Draft article by Thorold

Dickinson, 14 January 1965.

13 Charles Barr, 'A Rediscovery of Cinema', talk given at UCL as part of 'Thorold Dickinson and British Cinema: A Centenary Conference', 11 October 2003. Tape recording courtesy of Philip Horne.

14 Jonathan Hacker and David Price, Take Ten: Contemporary British Film

Directors (Oxford: Clarendon Press, 1991), p. 248.

15 Email from Lutz Becker to author, 17 November 2014.

16 Timothy Hyman, 'Talking to Derek Jarman', London Magazine, vol. 20, no. 7, October 1980, p. 72.

17 BFI Special Collections, Thorold Dickinson papers, Box 34, Folder 1: Amended programme for 'Backgrounds of American History', dated 27 September 1963.

${ }^{18}$ Annette Kuhn, Family Secrets: Acts of Memory and Imagination (London: Verso, 1995), p. 109, p. 112.

${ }^{19}$ V. I. Pudovkin, On Film Technique (London: Victor Gollancz, 1929), p. 15.

20 Thorold Dickinson and Michael Orrom, 'The Start at the Slade', Film, MarchApril 1961, p. 24.

21 Mulvey and Wollen op. cit., p. 218.

22 Slade Film Department archive, UCL, Box 2: Letter from Thorold Dickinson to Brian Finney, 10 December 1964.

23 Thorold Dickinson, 'Has the Cinema Grown Up?', Films and Filming, July 1964, p. 46.

${ }^{24}$ Charles Barr, 'A Rediscovery of Cinema', in Philip Horne and Peter Swaab, (eds), Thorold Dickinson: A World of Film (Manchester: Manchester University Press, 2008), p. 132.

25 Dickinson op. cit., p. 47.

26 O’Pray op. cit., p. 138.

27 Derek Jarman, The Last of England (London: Constable, 1987), pp. 97-9.

28 UCL Slade Film Department Archive, Box 13: Thorold Dickinson, 'Inaugural Lecture', January 1969.

${ }^{29}$ Jarman, The Last of England, p. 185. 
30 Telephone interview with Lynn Hanke, 9 November 2014.

31 Derek Jarman, War Requiem: The Film (London: Faber and Faber, 1989), p. 10.

32 Slade Film Department archive, Box 7j: 'Study of the Film' (annual report), signed Slade Film Department, April 1967.

33 Thorold Dickinson, 'Should Britain Have a Film School?', transcript of talk delivered at UCL on 5 March 1963, p. 2. Held by BFI Library.

34 Ibid.

35 Thorold Dickinson, 'The Study of the Film', Screen Education Year Book 1962, p. 16.

36 Becker email, op. cit.

37 Slade Film Department archive, UCL, Box 7j: 'Slade Film Unit: Report' by Mirek Dohnal, c. mid-1969.

38 Slade Film Department archive, UCL, Box 7k: Minutes of Slade School committee meeting, 5 February 1969.

39 Slade Film Department archive, UCL, Box 16: Letter from Thorold Dickinson to William Coldstream, 10 September 1969. 